\title{
Postfire macromycetes from deciduous wood in the Chrzanów forest inspectorate (S Poland)
}

\author{
EWA DYLAQG and BARBARA GUMIN̈SKA \\ Institute of Botany, Jagiellonian University \\ Lubicz 46, PL-31-512 Kraków, Poland
}

D y 1 a g E, Gu mitis $\mathrm{k}$ a $\mathrm{B}$ : Posyfire macromycetes from deciduous wood in the Chranow forest inspectorate (S Poland). Acta Mycol. 32 (2): 173-187, 1997.

The paper presents the results of the studies of postfire macromyceles in a burnt forest near Chrzanow. Fifty one species of fungi and three species of Myxomycetes were found in the investigated area. Pholiota carbonaria was the most abundantly fructifying fungus. Its seasonal frequency was observed on 8 sample plots $(1 \mathrm{~m} \times 1 \mathrm{~m})$ over two subsequent years: 1993 and 1994. Gradual overgrowth of the plots by mosses, flowering plants and other fungi was also observed.

Key words: burnt forest, occurrence of the fruit bodies, postfire macromycetes.

\section{INTRODUCTION}

The hot summer of 1992 contributed to sufficient forest fire conditions in various parts of Poland. In the Byczyna forestry (Chrzanow forest inspectorate, province of Katowice), a very intense fire started on June 28, 1992 and lasted until July 13. The fire consumed both the tree layer and the ground vegetation (herb layer). In total 19.9 hectares of forest were burnt (sections $47 \mathrm{f}$ and $47 \mathrm{~d}$, see Fig. 1). This area is a part of the Chrzanow Basin (Kotlina Chrzanowska) forest complex, north-west from Chrzanów, stretching towards the Przemsza River. The burnt area was a marshy coniferous forest (Vaccinio uliginosi-Pinetum). The tree layer was mainly composed of pine (Pinus sylvestris), with birch (Betula verrucosa) and spruce (Picea abies). The shrub layer was mainly composed of Frangula alnus, Sorbus aucuparia and Cerasus avium. The herb layer contained Athyrium filix-femina, Calamagrostis epigeios, Deschampsia flexuosa, Eupatorium cannabinum, Juncus effusus, Molinia arundinacea, $M$. coerulea, Pteridium aquilinum, Trientalis europaea, Vaccinium uliginosum and others. 
The dominant soil type in this area is gley classified in the category of marshy soils. A detailed soil analysis performed by the Department of Plant Ecology, Jagiellonian University, 130 days after the fire indicated significant differences in the chemical composition between soil samples from burnt and unburnt areas of the forest (Table 1). The resulting table indicates that the effects of fire in the burnt section of the forest were higher soil acidification, an increase in organic matter and total nitrogen contents, an increase in soluble soil components and a higher concentration of exchangeable cations in the soil sorption complex.

Ta ble 1

Results of the soil analysis of the postfire forest site from both burnt and unburnt areas of the Byczyna forestry in 1994

\begin{tabular}{|c|c|c|c|c|c|c|c|c|c|c|c|c|c|}
\hline \multirow[t]{2}{*}{ Area } & \multicolumn{2}{|c|}{$\mathrm{pH}$ in } & \multirow{2}{*}{$\begin{array}{c}\text { Organic } \\
\text { matter } \\
{[\%]}\end{array}$} & \multirow{2}{*}{$\begin{array}{c}\text { Total } \\
\text { nitrogen } \\
{[\%]}\end{array}$} & \multicolumn{4}{|c|}{$\begin{array}{l}\text { Assimilable compounds } \\
\text { [mg/100 } \mathrm{g} \text { of soil] }\end{array}$} & \multicolumn{4}{|c|}{$\begin{array}{l}\text { Exchangeable cations } \\
\text { [mg/100 } \mathrm{g} \text { of soil }]\end{array}$} & \multirow{2}{*}{$\begin{array}{l}\text { Total } \\
\text { cations }\end{array}$} \\
\hline & $\mathrm{H}_{2} \mathrm{O}$ & $\mathrm{KCl}$ & & & $\mathrm{K}_{2} \mathrm{O}$ & $\mathrm{P}_{2} \mathrm{O}_{3}$ & $\mathrm{MgO}$ & $\mathrm{CaO}$ & $\mathrm{Ca}$ & $\mathrm{Mg}_{\mathrm{g}}$ & K & $N_{a}$ & \\
\hline & 4.42 & 38 & 80. & 0.19 & 5.5 & 26 & 6 & 49 & 0.43 & 0.3 & 0.26 & 0.05 & 1.04 \\
\hline burnt & 3.50 & 2.90 & 47,77 & 1.45 & 25.5 & 38 & 28 & 94.5 & 3.62 & 1.46 & 1 & 0.2 & 6.28 \\
\hline
\end{tabular}

One year after the fire, the forest authority of this region performed a set of routine maintenance activities. Partially burnt trees and shrubs were cut and burnt in two large pyres. This action resulted in a high number of trunks and remnants of smaller or larger branches and fragments of wood covering the soil. This material was a perfect habitat for the growth of fungi (mainly saprotrophic species). At the beginning of 1993, the burnt grounds were ploughed to create a number of drainage ditches. The areas between ditches were planted with young trees. Herbs started to appear as well (Fig. 2).

The initial area selected for the mycological investigations was 80 acres. Later, this turned out to be far too small and was increased to 9 hectares in 1994. The aims of this study were as follows:

a) to investigate the species composition of postfire macromycetes,

b) to observe the fructification of Pholiota carbonaria.

The observations were carried out over two vegetative seasons (1993 and 1994). During both seasons 30 observations were made, with a frequency of about every two weeks. Additionally, single observations in November and December of 1992 were carried out. The meteorological information on this area (precipitation and temperatures) used in this study was provided by the measurement station at Balice near Kraków (Institute of Weather Forecast and Water Management). 


\section{SPECIES COMPOSITION OF FUNGI IN THE BURNT FOREST}

Fifty one species of fungi and three species of Myxomycetes were identified in the burnt forest area. The presence of slime moulds was detected only during the second year of observations. The most frequent one was Lycogala epidendrum, which fructified with different intensities from the end of May to the end of August. It was frequently found on burnt trunks and protruding tree roots. In September, individual aethalia of Reticularia lycoperdon were found twice, on decaying wood. This slime mould occurred in a few sites only. Fuligo septica was found only once, on a rotten trunk.

Among the 51 identified species of fungi, only nine belong to the Ascomycetes, and 42 Basidiomycetes. Three species of Ascomycetes (Anthracobia maurilabra, Geopyxis carbonaria and Plicaria fuliginea), according to Moser's classification (1949), were typical anthracobionts, which means fungi found exclusively at burnt forest sites. In the burnt forest in Byczyna, the three species mentioned above fructified only occasionally, which is surprising in the case of Geopyxis carbonaria, as this fungus is one of the most common postfire species. Perhaps this was due to the advanced age of the postfire site. Observations began 20 weeks after the fire, and the sporophores of Geopyxis carbonaria, according to M o s e r (1949), appear mainly (but not only) during the first stages of fungal succession on a postfire site and most frequently in spruce forests.

Only a few sporophores of Plicaria fuliginea were found, and not a single sporophore of $P$. leiocarpa, a species usually very common to the postfire sites. G i n k o (1984) observed a very abundant fructification of $P$. leiocarpa (hundreds of sporophores on a surface of $10 \times 20 \mathrm{~m}$ eight months after the fire) in a burnt pine forest, near Zielona Góra.

Two species of the Ascomycetes (Rhizina inflata and Sphaerospora brunnea) were classified as anthracophilic fungi, according to M o s e r (1949). They are species primarily connected with postfire sites but may also occur elsewhere. This particularly applies to the Rhizina inflata. In spite of its rather strong affinity for postfire sites, it may occur in coniferous forests, especially pine woods, where it can infect the root collars of young trees like a typical parasitic xylobiont. It may cause particularly significant damage in reforesting nurseries. It should be emphasized that no species of Ascomycetes were observed, which could be attributed to anthracoxenic fungi, in accordance with M o s e r's (1949) classification. Anthracoxenic fungi occur in many different places, but may occasionally grow on postfire sites. Their development in this particular habitat is unrestricted. Four of the observed Ascomycetes were not at all connected with postfire sites: Daldinia concentrica and Nectria cinnabarina occurred on fallen, dead branches, Ascocoryne sarcoides on the surface of trunks and Aleuria aurantia on bare sandy soil, along the wide 
path through the site. The fructification of the last-mentioned species was abundant and lasted four weeks of September 1994.

Among 42 species of Basidiomycetes found on the postfire site, 18 belong in the order Aphyllophorales, 18 Agaricales, 2 Boletales, 2 Sclerodermatales, 1 Dacrymycetales and 1 Tremellales.

Species from the order Aphyllophorales are not typical for postfire habitats. High abundancy of these fungi resulted from the fact, that during removal of the burnt trees many scattered branches were left on the ground. Trunks of the removed trees also remained. All these fragments of wood were colonized by typical saprotrophs such as: Bjerkandera adusta, Polyporus arcularius, P. brumalis, Stereum hirsutum, S. sanquinolentum, Trametes hirsuta, T. versicolor and others. During two years of observations, facultative parasites such as Chondrostereum purpureum and Piptoporus betulinus were observed only once. Thelephora terrestris (common in autumn) occurred on basal parts of trunks or on the ground. This is a fungus often overgrowing the seedlings of coniferous trees, which may lead to serious damage in the reforesting nurseries, even though this fungus is not a parasite. Coltricia perennis (very common in pine forests) was only found four times (once in 1993 and three times in 1994). Among all observed Aphyllophorales only one species had some links with postfire habitats - Schizophyllum commune, which can be classified as an anthracoxenic fungus. In the investigated area, it was often found on semi-burnt trunks and branches.

Another large group of fungi (18 species) represents the order Agaricales. Among them were also species linked up with postfire habitats. The typical anthracobionts were Pholiota carbonaria, Tephrocybe ambusta and T. anthracophila. The first species fructified with particular abundance, its sporophores appeared from early spring to late autumn, throughout two vegetation seasons. Coprinus angulatus, Myxomphalia maura and Psathyrella pennata can be classified as typical anthracophilic fungi. Only the third mentioned species appeared more frequently, with some interruptions. Other species can also be related to postfire habitats, for example Galerina phillipsi, but because of the scarcity of data, it is impossible to classify this species to any of the groups specified by M o s e r (1949). This species was described by Reid in 1984 in the UK, it was found in a burnt pine and birch forest on acidic soil.

Only one of the species found at the site, Laccaria proxima of the order Agaricales, can be classified as a mycorrhizal fungus. Only in 1994 it fructified fairly abundantly and continuously from mid-September to the beginning of November. All the other fungi of the order Agaricales were typical terrestrial saprotrophs (e.g. Rickenella fibula, Gymnopilus fulgens and Mycena galopoda) or lingnicolous saprotrophic fungi, mainly on trunks (e.g. Gymnopilus penetrans, Hypholoma fasciculare and Pluteus atricapillus). 
The other orders of fungi were represented by a few species. Four of them were typical mycorrhizal fungi: two from the order Boletales (Hygrophoropsis aurantiaca and Paxillus involutus) and two from the order Sclerodermatales (Scleroderma citrinum and S. bovista). Some wood-decaying saprotrophs belonged in the order Dacrymycetales (Dacrymyces stillatus) and Tremellales (Tremella foliacea).

As a result of two years of observations in a burnt forest it was found that the most frequently occuring species was Pholiota carbonaria (29 identifications/32 observations). There were many species that were observed only once (13 species) or twice (12 species), the others occurred accidentally. Perennial fungi were frequently observed on wood or semi-burnt branches. It is interesting that the first fungi on the postfire forest site appeared very early after the winter period. Species such as Geopyxix carbonaria, Pholiota carbonaria, Rickenella fibula and Strobilurus stephanocystis fructified in the second half of April (except for the perennial fungi). This can be explained by the stronger heating of the soil in spring, due to better insolation after removal of partially burnt trees (especially pines). It is also characteristic that the fructification period extended until late autumn. As late as mid-December (both in 1992 and the subsequent years) fructification of numerous leathery lignicolous saprotrophs and some fleshy fungi such as Anthracobia maurilabra, Ascocoryne sarcoides, Gymnopilus penetrans, Pholiota carbonaria and Tremella foliacea was observed.

\section{DETAILED INSTIVEGATIONS OF PHOLIOTA CARBONARIA ON SAMPLE PLOTS}

The first sporophores of Pholiota carbonaria were observed at the investigated site at the end of November 1992, which was the twentieth week after the fire. Their fructification lasted (with variable intensity) until the end of November 1994. To assess quantitatively the fructification intensity of Ph. carbonaria, eight permanent sample plots were established in September 1993, sized $1 \mathrm{~m} \times 1 \mathrm{~m}$. Detailed quantitative observations were made on each of them, according to the following schedule:

$1993-10.09,16.10,29.10$ and 15.11

$1994-23.08,30.08,10.09,23.09,02.10,13.10,24.10,03.11$ and 14.11 . Each observation comprised the information about the number of $P h$. carbonaria sporophores and the description of successional changes on the plot. A total of 13 observations were made during the two vegetation seasons. 


\section{Results of particular observations}

follows:

The number of observed sporophores on particular plots were as

10.09.1993 - fructification fairly abundant (Fig. 3); 861 sporophores observed on all the plots.

16.10.1993 - fructification very abundant; 1180 sporophores observed on 8 plots.

29.10.1993 - as compared to the previous observation, fructification much lower; 481-sporophores observed on all the plots.

15.11.1993 - fructification still quite abundant despite the unfavorable weather conditions; 380 sporophores observed on 8 plots.

23.08.1994 - fructification poor; 17 sporophores observed on all the plots.

30.08.1994 - fructification poor; 20 sporophores observed on all the plots.

10.09.1994 - fructification poor; 17 sporophores observed.

23.09.1994 - fructification poor; 19 sporophores observed.

02.10.1994 - fructification poor; 21 sporophores found on all the plots.

13.10.1994 - fructification poor: 13 sporophores found on all the plots.

24.10.1994 - fructification very scant; 4 sporophores found on one plot and no fungi on any other plot.

03.11.1994 - despite good weather conditions no sporophores found on the plots.

14.11.1994 - fructification very scant; 4 sporophores found on one plot and no fungi on any other plot.

\section{Comparison of fructification between the two observation years}

The above data indicate that fructification of Pholiota carbonaria in 1993 and 1994 differed significantly (abundant in 1993 and poor or even very scant in 1994, Table 2). Whereas in 1993 sporophores were found on the plots during all the season (with some exceptions in mid-December), in the following year on four of the plots (No 4, 5, 6 and 8) no sporophores were found at. It is interesting to compare corresponding observations from the two years. The comparision below shows the total numbers of sporophores recorded on a given day on all the plots.
10.09.1993 - 861 sporophores - 10.09.1994 - 17 sporophores
16.10.1993 - 1180 sporophores - 13.10.1994 - 13 sporophores
$23.10 .1993-481$ sporophores $-24.10 .1994-4$ sporophores
15.11 .1993 - 380 sporophores - 14.11.1994 - 4 sporophores 
Table 2

Fructification of Pholiota carbonaria on eight permanent plots $(1 \mathrm{~m} \times 1 \mathrm{~m})$ on the burnt forest site in the Byezyna forestry in 1993 and 1994 (number of sporophores on the $y$-axis).
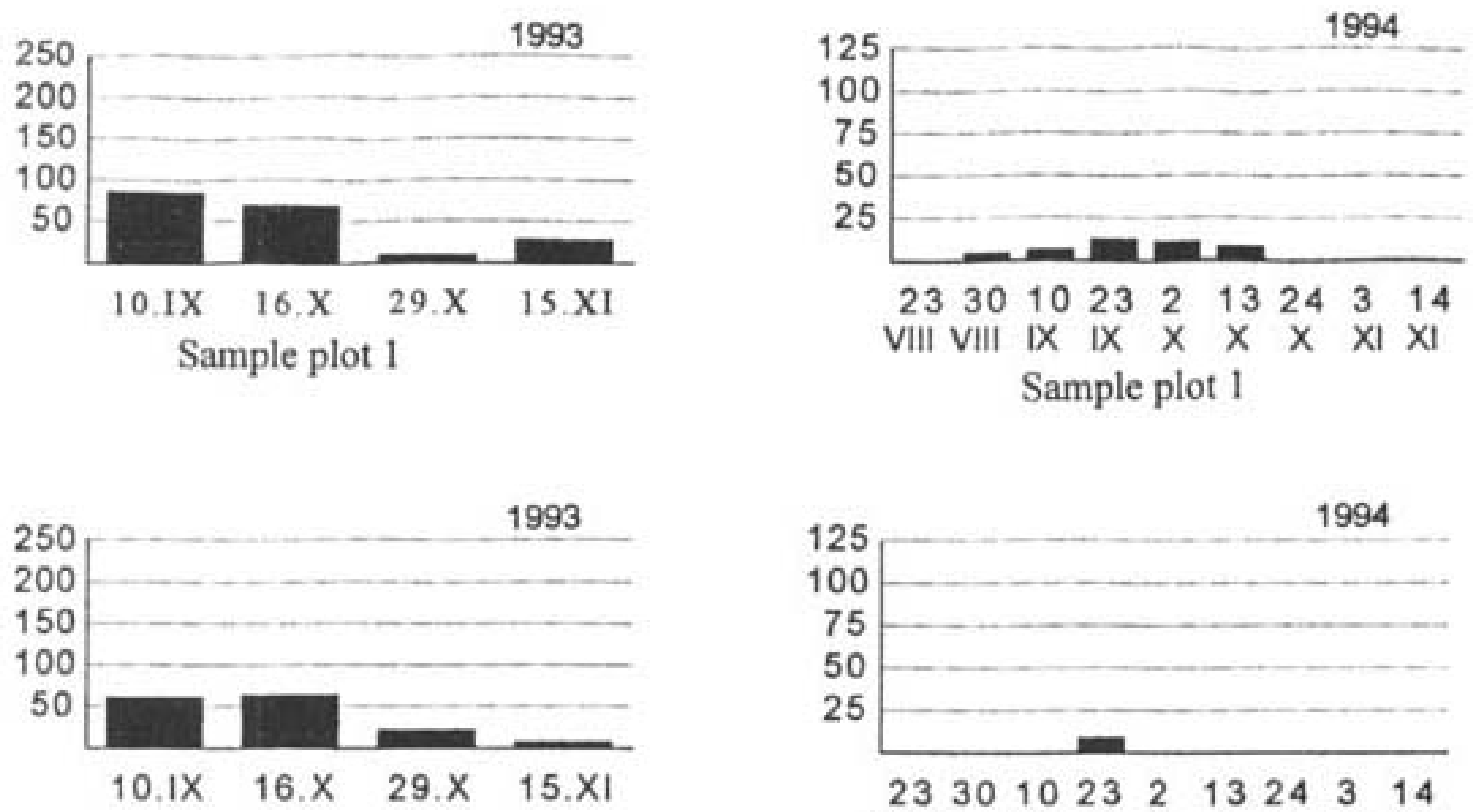

Sample plot 2

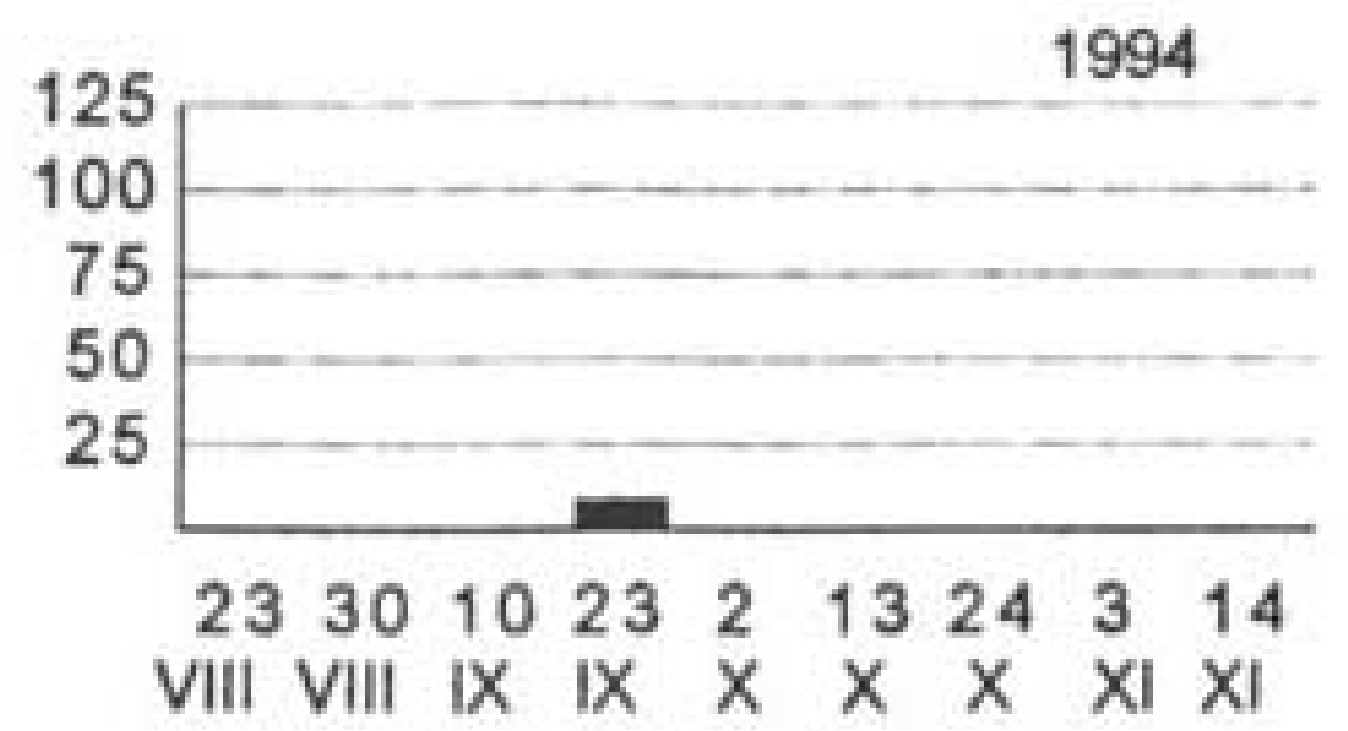

Sample plot 2
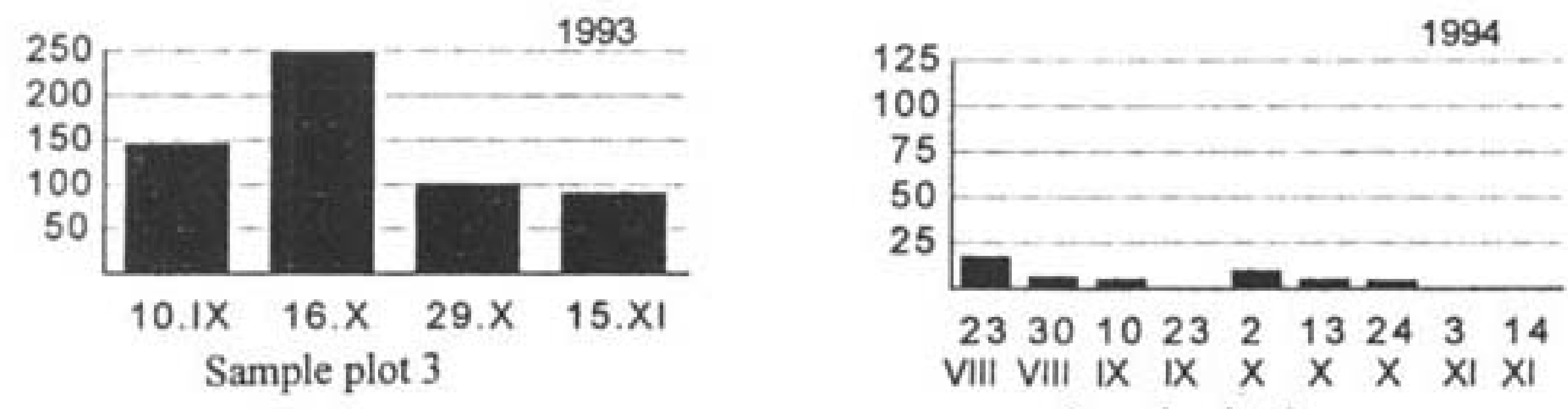

Sample plot 3
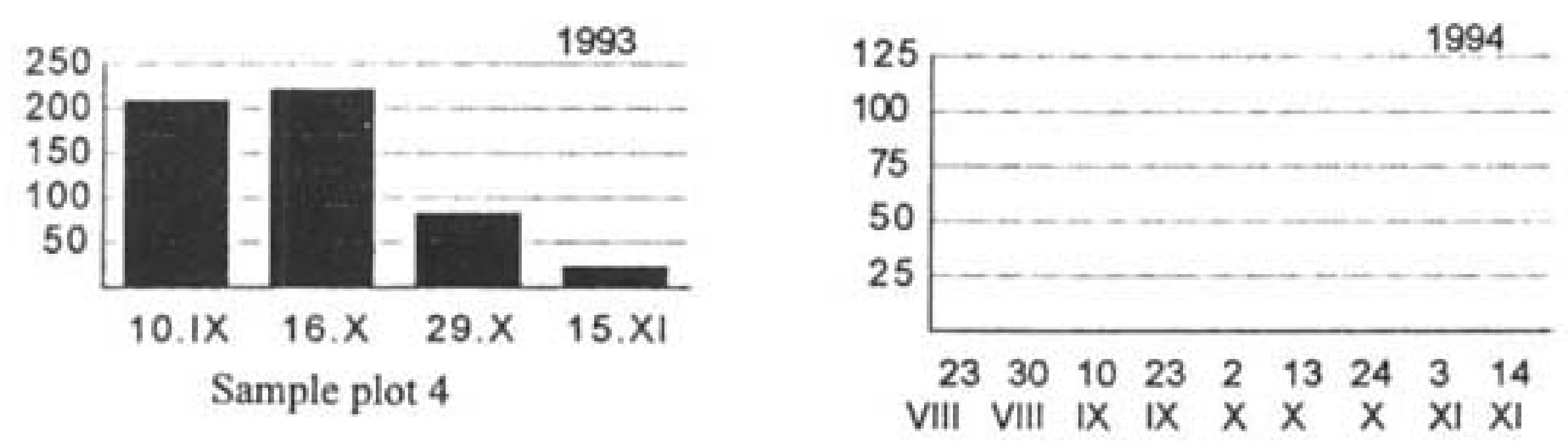

Sample plot 4 
cont. Table 2

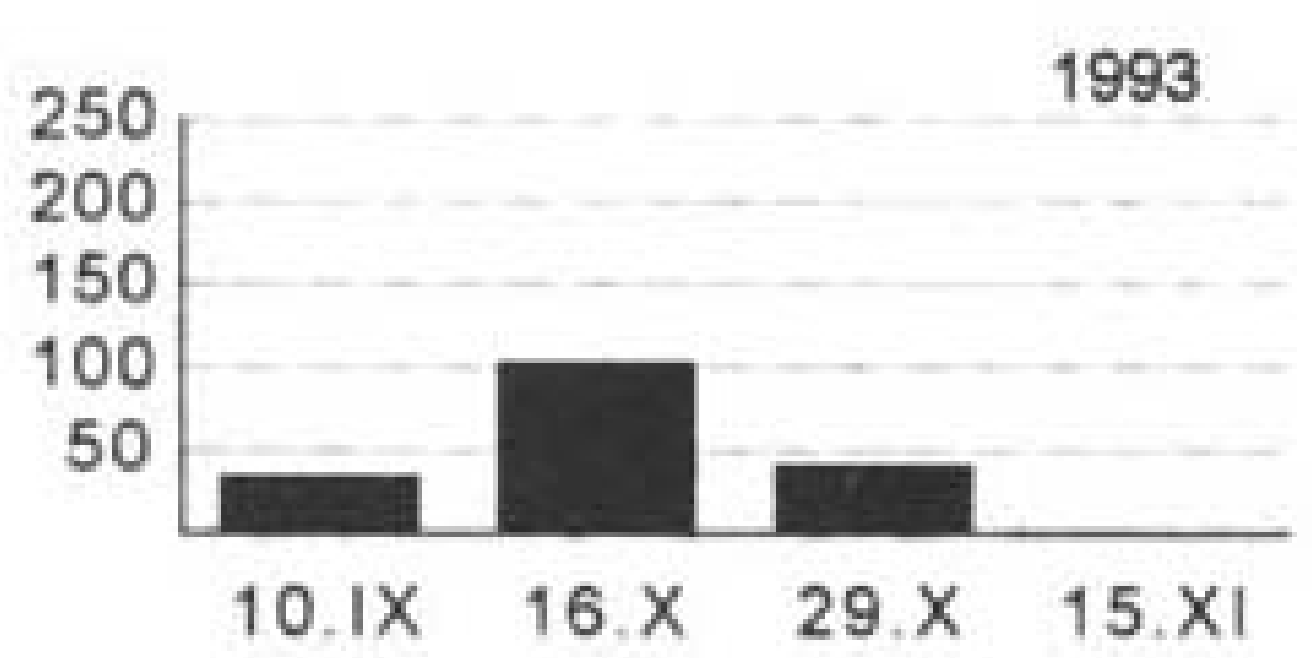

Sample plot 5
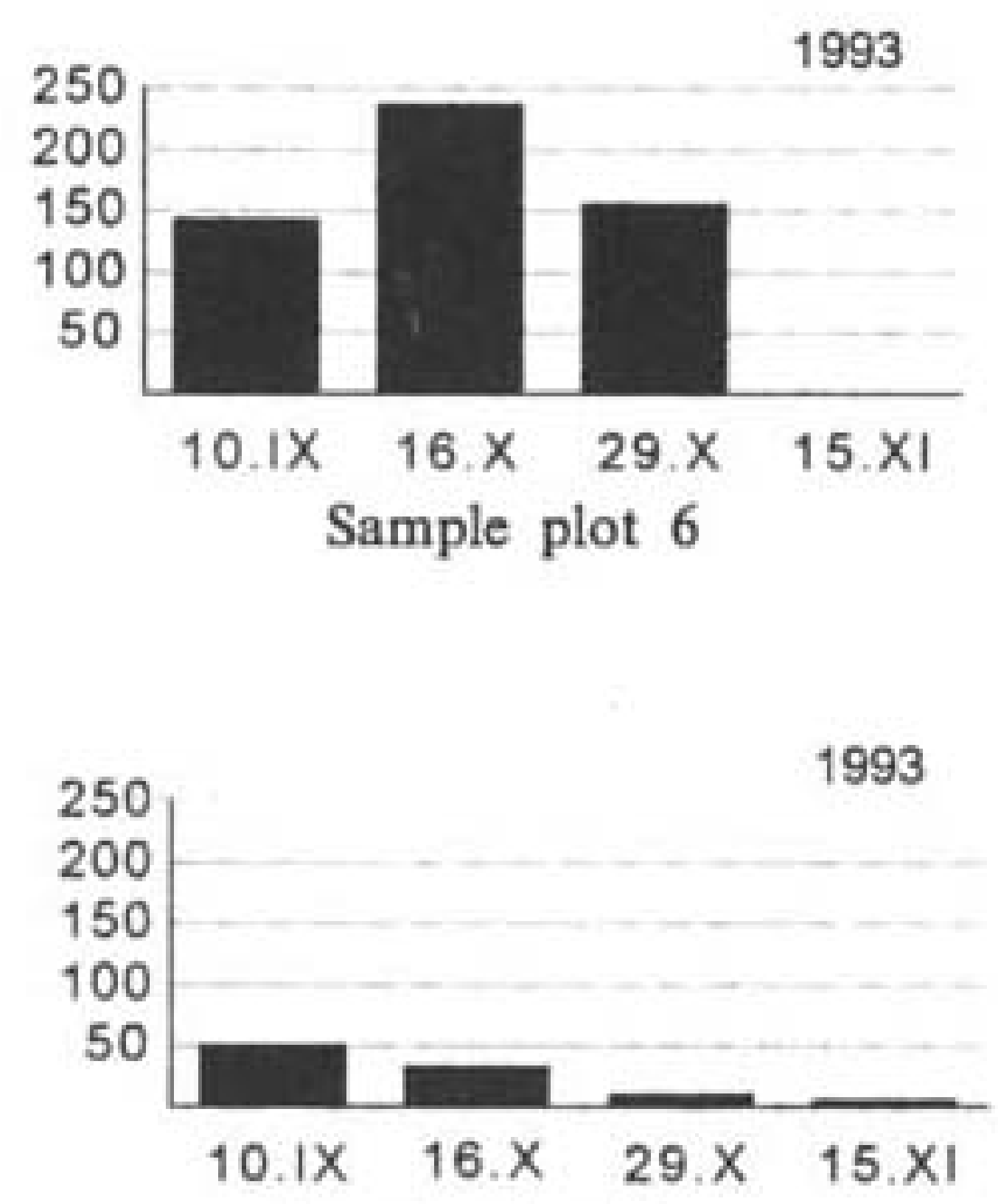

Sample plot 7

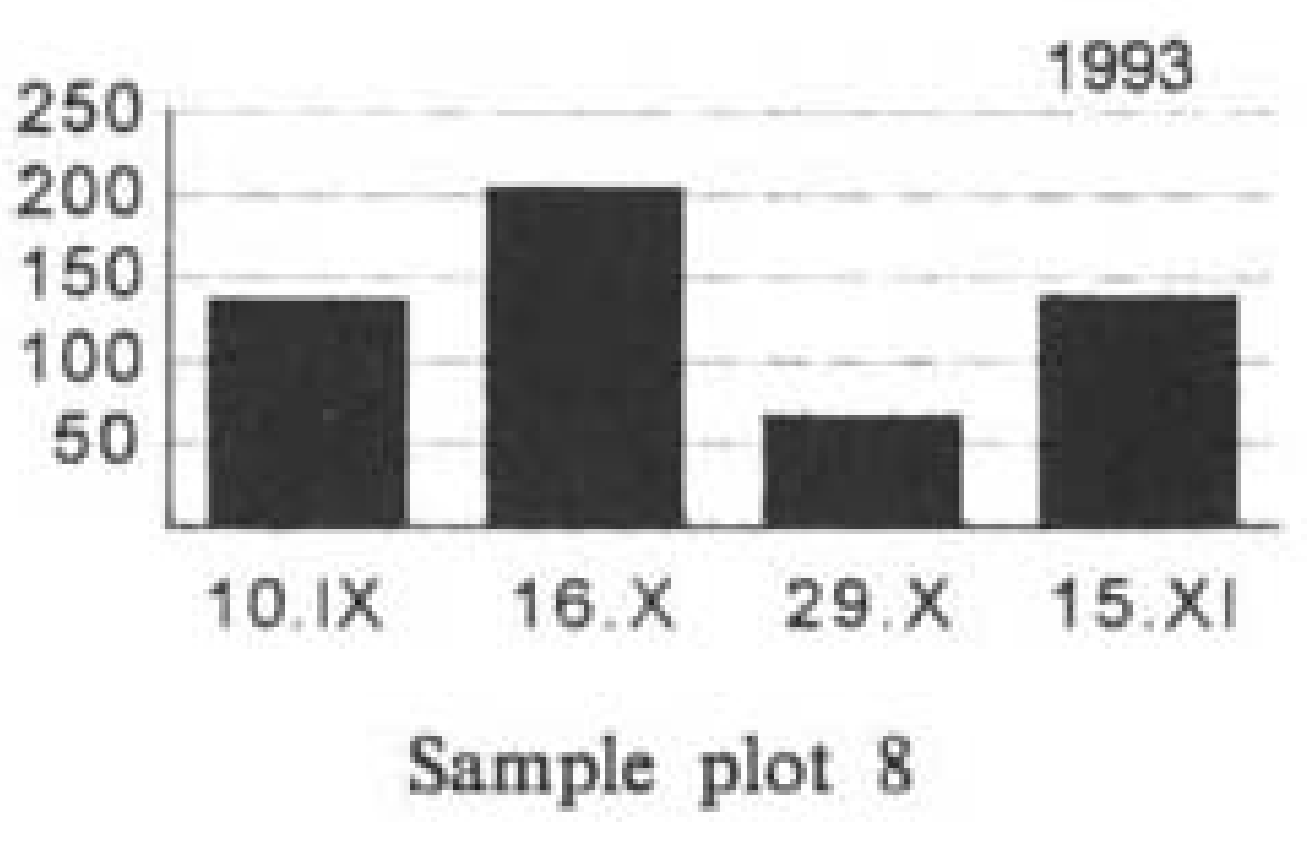

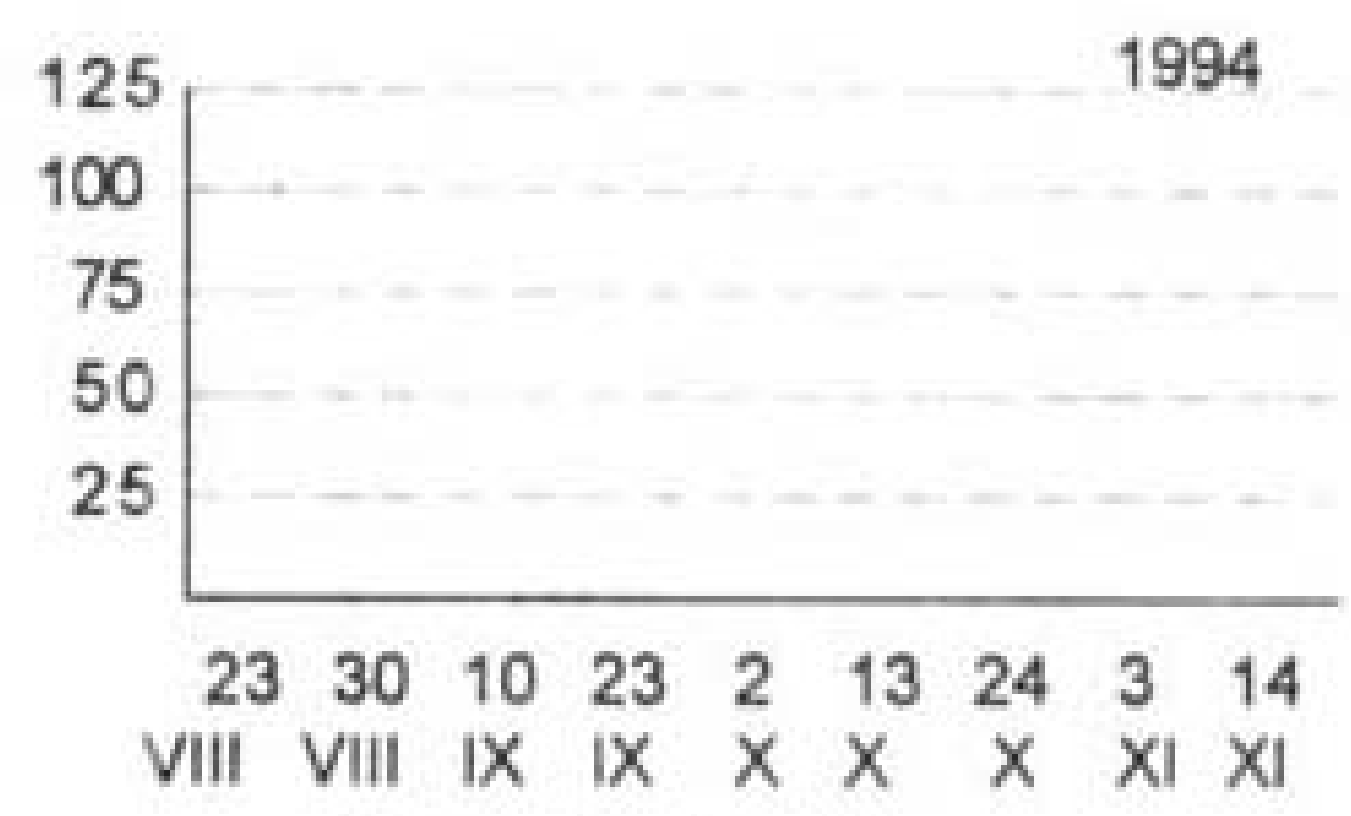

Sample plot 5
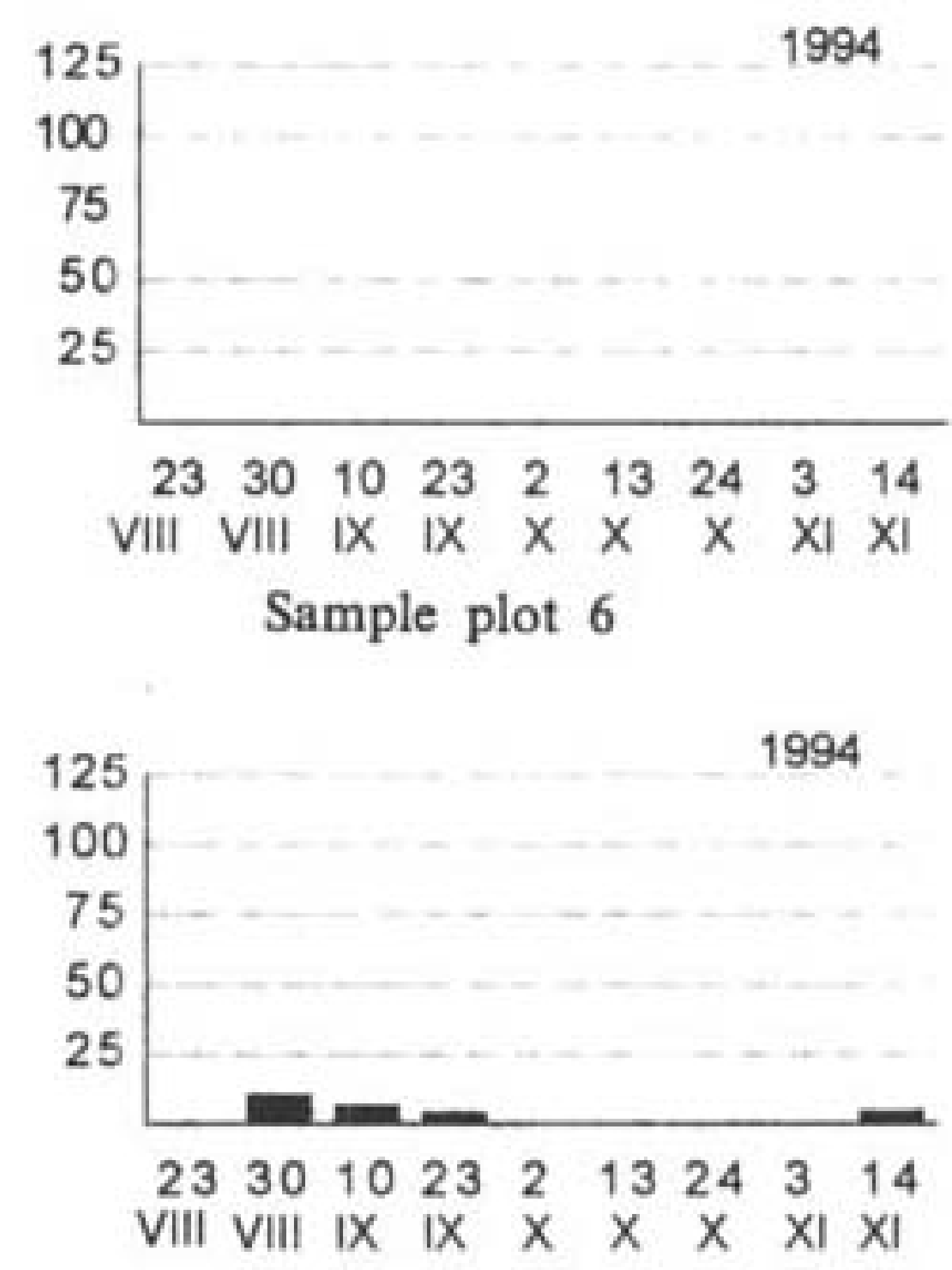

Sample plot 7

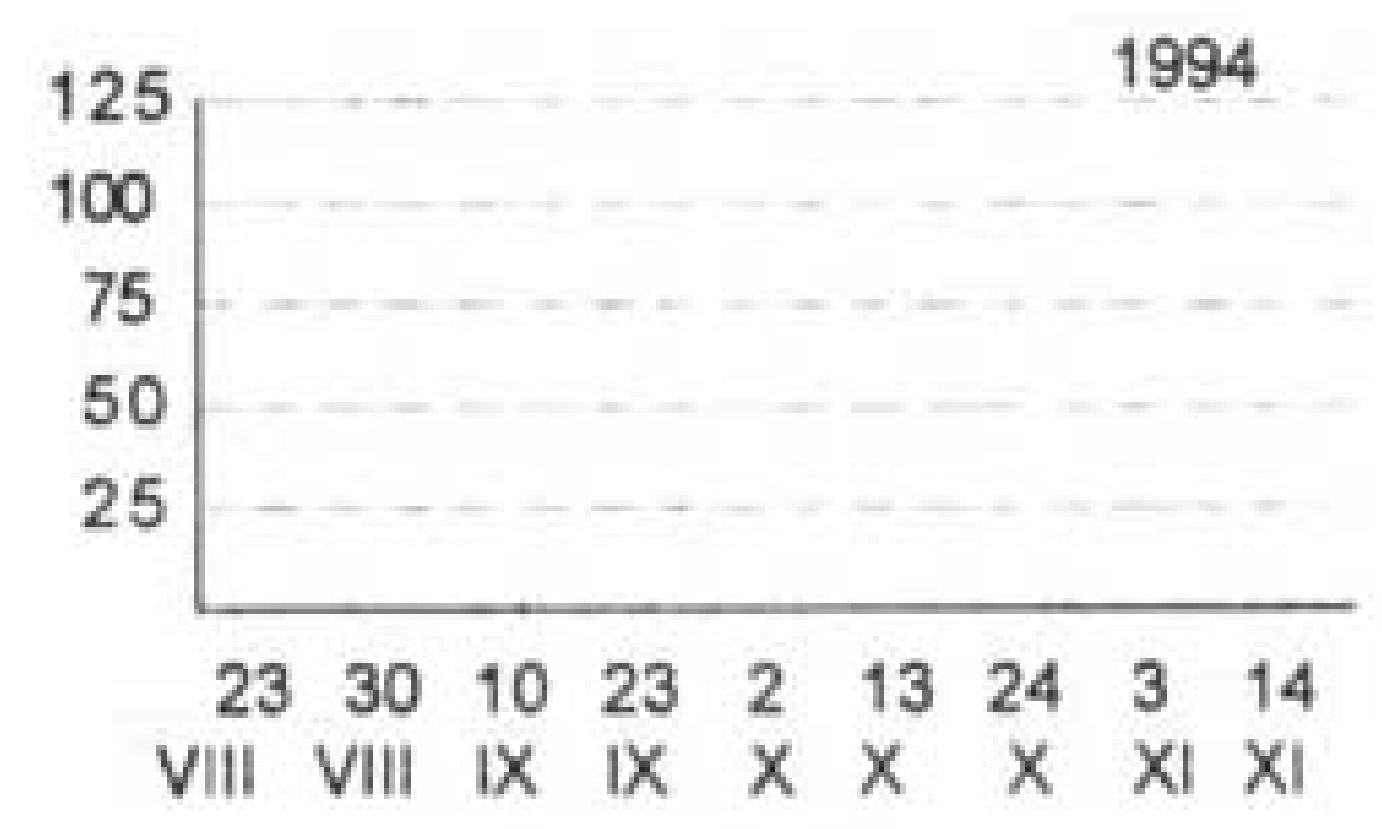

Sample plot 8 


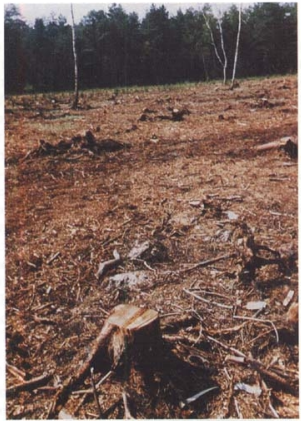

Fig. 1. Burnt forest in the Byczyna forestry, 20 weeks after the fire

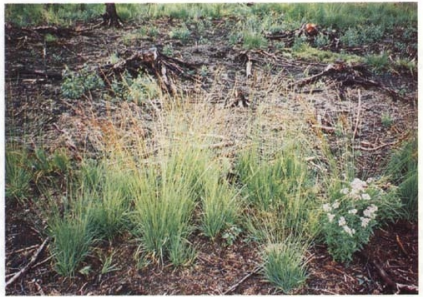

Fig. 2. Bundles of grasses (Molinia arundinacea and Eupatorium camabinum) on the background of the burnt forest on week 63 after the fire (August 1993) 


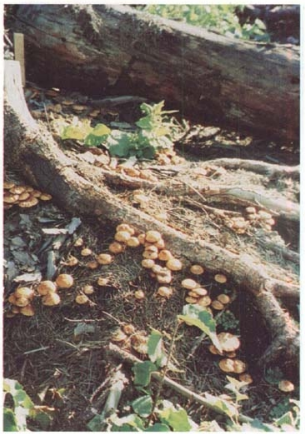

Fig. 3. Sporophores of Phoitota carbonaria on plot 5, week 65 after the fire (observation made on September 10, 1993)

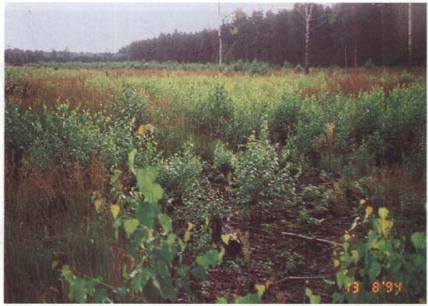

Fig. 4. Burnt forest in the Byczyna forestry, 113 weeks after the fire (August 1994) 
These very striking differences may result from three reasons.

1. Different weather conditions in 1993 and 1994 . The year 1993 was very advantageous for fungi fructification. Starting from mid-June to the end of July it rained every day, and the temperatures sometimes exceeded $30^{\circ} \mathrm{C}$ (during the first half of August). In September the precipitation was less frequent, but ambient temperatures remained high. Even October was exceptionally warm, there were many days with temperatures over $20^{\circ} \mathrm{C}$ in the first half of the month. In mid-October there were strong rainfalls, creating optimum conditions for fructification. Significant temperature drops, including morning frosts, were recorded at the end of the month. November was cool, even though ambient temperatures in the first half of the month reached $15^{\circ} \mathrm{C}$, snowfalls occurred in its second half.

In 1994 the summer was very dry and hot. Starting from mid-June till the beginning of August there were long (12- to 15-day) periods with no rain and very high temperatures. At the end of July and the beginning of August they exceeded $30^{\circ} \mathrm{C}$ for several days. The soil dried out and cracked in some areas. This results in the lack of fungi not only in summer but also in autumn. In the beginning of September temperatures remained high, reaching $28.8^{\circ} \mathrm{C}$ (on September 8), with low precipitation level. More abundant rainfalls occurred in the second half of September, but they did not intensify the fructification of Pholiota carbonaria. October was quite warm as well, with some morning frosts. November was cool with frequent frosts, on November 14 water filling the postfire area drainage ditches froze $(1 \mathrm{~cm}$ layer of ice).

2. Natural exhaustion of the mycelium's growth potential (after intense fructification during the previous year). With time, the capacity of the mycelium to form sporophores may have decreased.

3. The presence of newcoming plants and other fungi, which gradually began to colonize the postfire area and competed with Pholiota carbonaria.

\section{Succession changes on the plots}

During two years of observations, the appearance of the eight investigated plots changed. During the vegetative season of 1993 (one year after the fire in June 1992), no sporophores other than abundant fruitbodies of Pholiota carbonaria were found on the plots (except for one site). The first mosses, liverworts and higher plants appearing on the ground were not yet exuberant and did not penetrate the plots.

In 1994 the appearance of the postfire area changed significantly. Outgrowths and seedlings of birch started to grow in a very intense way; at the end of the year some of them reached $1.8 \mathrm{~m}$ (Fig. 4). 
Both birch seedlings and other intensively growing plants started to colonize the plots:

- in plot no. 2 numerous birch seedlings appeared,

- in plot no. 3 the moss Ceratodon purpureus took over one third of the area,

- in plot no. 5 one corner of the square was overgrown by the grass Calamagrostis epigeios,

- in plot no. 6 the grass Molinia arundinacea dominated $2 / 3$ of the area,

- in plot no. 7 a large individual bundle of the rush Juncus effusus and numerous birch seedlings appeared,

- in plot 8 there were several small bundles of Juncus effusus.

Fructification of fungi on the plots changed radically in 1994. Through natural succession, Pholiota carbonaria was replaced by other fungi, taking over the plots:

Coprinus angulatus - in August and September several sporophores of this

typical anthracophilic fungus appeared on plots no. 1, 4 and 5;

Laccaria proxima - from September till mid-November this fungus fructified

on plots 4,5 and 6 , even though it is not closely associeted with fireplaces;

Paxillus involutus - several sporophores of this species (not typical for postfire sites) appeared in plot no. 4 by the end of August and again in October; Psathyrella pennata - this typical anthracophilic fungus, together with Pholiota carbonaria, appeared in plot no. 5 during the 1993 vegetative season (fairly frequently but in low numbers of sporophores). In August and September 1994, on the same plot, it fructified much more abundantly: e.g. 22 sporophores on August 30, 28 sporophores on September 10. It was also observed on plots 1 and 4 .

Lycogala epidendrum - slime moulds were observed only in 1994, always outside the plots. Only on plot no. 1, on August 23 there were 19 aethalia of this species present on the semi-burnt tree roots protruding from the ground. No Pholiota carbonaria sporophores were found on this plot the same day.

Through natural succession over the following years, the postfire area will be colonized by the renewing forest.

\section{LIST OF SPECIES}

\section{MYXOMYCETES}

Fuligo septica Gmelin - found once on a decaying trunk.

Lycogala epidendrum $\mathrm{Fr}$. - on burnt trunks and partially burnt protruding tree roots. Observed also by other authors (P e ters e n 1970) on postfire sites.

Reticularia lycoperdon Bull. - fructified in September 1994 on decaying wood. 


\section{ASCOMYCETES}

\section{Pezizales}

Aleuria aurantia (Fr.) Fuck. - fructified very abundantly in September 1994 only, on bare ground along the main path across the site. Fructification lasted about four weeks.

Anthracobia maurilabra (Cooke) Bound. - the occurrence of this species was observed only in 1992 (November and mid-December) in patches of the moss Funaria hygrometrica. It is not a rare fungus, T u $\mathrm{r} \mathrm{n}$ a u (1984) observed it on postfire sites in the Gorce Mountains between June and September. Geopyxis carbonaria (Alb. et Schw.:Fr.) Sacc. - common postfire fungus, observed only twice in the studied area (second half of April 1993). Its fructification was very abundant (about 400 sporophores per $\mathrm{m}^{2}$ ). It did not appear in further observations.

Plicaria fuliginea Schum. - found once on May 5, 1994, small number of sporophores growing on the ground.

Rhizina undulata $\mathrm{Fr}$. - this fungus is a facultative pathogen, infecting the root collars of seedlings and young coniferous trees (pine in particular). It often grows on fresh postfire sites. In the area studied it fructified abundantly in 1993 (between June and August) in the following year it was found only once, in the second half of September. It often occurs on the borders of postfire sites (P e t e r s e n 1970), which indicates a certain relation with the degree of soil burning.

Sphaerospora brunnea (Alb. et Schw.) Mass. - found twice during the second half of September 1994 and at the end of October 1994, on bare ground.

\section{Helotiales}

Ascocoryne sarcoides (Jacq.) Groves et Wilson - observed in late autumn only (mid-November to mid-December) on the surface of trunks.

\section{Sphaeriales}

Daldinia concentrica (Bolt.: Fr.) Ces. et de Not. - often found on dead branches laying on the ground (September to November).

Nectria cinnabarina (Tode: Fr.) - found once in November 1994 on a laying branch (conidial stadium).

\section{BASIDIOMYCETES}

\section{Tremellales}

Tremella foliacea (Pers.) Pers. - it fructified on trunks only in 1994, in two different time periods: May to June and November to December. 


\section{Dacrymycetales}

Dacrymyces stillatus Nees: $\mathrm{Fr},=D$. deliquescens (Bull.: Fr.) Duby - found once on a dead trunk.

\section{Aphyllophorales}

Bjerkandera adusta (Wild.: Fr.) P. Karst. - frequently found on decaying wood, in autumn 1994.

Chondrostereum purpureum (Pers.: Fr.) Pouz. - found once on a trunk, in

September 1994.

Coltricia perennis (L.: Fr.) Murr. - fructified in August 1993, and in September and October 1994, on dry sandy soil.

Gloeophyllum sepiarium (Wulf:: Fr.) P. Karst. - found once, in December 1994, on a semi-burned log.

Panus conchatus (Bull.: Fr.) Fr. - a few specimens observed in 1994 on trunks.

Piptoporus betulinus (Bull.: Fr.) P. Karst. - found once, at the beginning of November 1994, on a birch branch.

Polyporus arcularius (Batsch) Fr. - occasionally found on fallen branches (1993 and 1994).

Polyporus brumalis Pers.: Fr. - fructified in 1993 and 1994, mainly in November and December, on branches laying on the ground.

Schizophyllum commune $\mathrm{Fr}$.: $\mathrm{Fr}$. - common at the investigated postfire site, often found on semi-burned trunks and branches.

Stereum hirsutum (Willd.: Fr.) S.F. Gray - common in the observed area, occurred on trunks and laying branches.

Stereum sanguinolentum (Alb, et Schw.: Fr.) Fr. - found twice, in late autumn, on semi-burned pine trunks.

Thelephora caryophyllea Schaeff:: Fr. - occasionally found on the ground or at the basis of trunks.

Thelephora terrestris Pers:- Fr. - found fairly frequently between August and November, on the ground or at the basis of trunks.

Trametes hirsuta (Wulf.: Fr.) Pil. - one of the most common species, found on trunks and fallen branches from spring to late autumn, during both vegetative seasons.

Trametes pubescens (Schum.: Fr.) Pil. - found once on a decaying trunk in October 1994.

Trametes versicolor ( $\mathrm{L}_{\text {.: }} \mathrm{Fr}$.) Quél. - common in the entire postlire area, on trunks and branches.

Trametes zonata (Nees: Fr.) Pil. - found once on a semi-burned trunk in October 1994. 
Trichaptum hollii (J.C. Schmidt: Fr.) Kreisel $=T$, fuscoviolaceum (Ehrenb.: Fr.) Ryv. - found once, on a trunk in November 1992.

\section{Boletales}

Hygrophoropsis aurantiaca (Wulf.: Fr.) R. Maire - the sporophores appeared once, in November 1992, on sandy soil.

Paxillus involutus (Batsch: Fr.) Fr. - it fructified in autumn, in both vegetative seasons, abundantly, on the ground near birch trees mainly.

\section{Agaricales}

Coprinus angulatus Peck $=$ C. boudieri Quél. - frequent postfire species, found once in 1993 at the end of August. In 1994 it fructified from the end of August to the end of September.

Galerina phillipsi Reid - found once in September 1994, on the ground, among mosses (det. Z. Heinrich).

Gymnopilus fulgens (Fav. et Maire) Sing. - found once, in September 1994, on the ground, in a bundle of moss (det. Z. Heinrich).

Gymnopilus penetrans ( $\mathrm{Fr}_{\mathrm{r} .}$ Fr.) Murr. - found once, in 1994, on fallen branches.

Gymnopilus sapineus ( $\mathrm{Fr}$.) Maire - found once, at the end of September 1994 on a trunk.

Hypholoma fasciculare (Huds.: Fr.) Kummer - occasionally found at the bases of trunks in autumn.

Hypholoma sublateritium (Fr.) Quél. - found twice in autumn 1994, on a decaying trunk.

Laccaria proxima (Boud.) Pat. - it fructified on sandy soil from September to November 1994.

Mycena galopoda (Pers.: Fr.) Kummer - occasionally found on the ground in autumn 1994.

Myxomphalia maura (Fr.) Hora - found once in the first days of November 1994 among carbonized remnants of wood. Typical postfire species.

Pholiota carbonaria (Fr.) Sing. - the most frequently fructifying fungus in the investigated area (Fig. 4). Its fructification lasted consecutively from spring to late autumn, over both vegetative seasons. It is the most typical postfire species. Its fructification on the site studied was analyzed in details.

Pluteus atricapillus (Batsch) Sing. - found once, in September 1994 on a decaying trunk.

Psathyrella pennata ( $\mathrm{Fr}$.) Konr. et Maubl. - fructified fairly frequently in summer and autumn, during both vegetative seasons. It was also accidentally observed in May and June. This fungus is morphologically 
similar to a few other species from the genus Psathyrella. A very good color photograph of this fungus as well as a description of the structure of its sporophores and microscopic details is given in $\mathrm{B} \mathrm{r}$ a n d and P e g 1 e r (1991).

Psilocybe crobula (Fr.) Kühn, et Romagn. - found once, in October 1994. Rickenella fibula (Bull.: Fr.) Raith. - occasionally found between spring and autumn 1994, on the ground, often among specimens of Marchantia polymorpha.

Strobilurus stephanocystis (Hora) Sing. - fructified on pine cones, only in April, during both vegetative seasons.

Tephrocybe ambusta ( $\mathrm{Fr}$.: $\mathrm{Fr}$.) Donk = Lyophyllum ambustum (Fr.) Sing. - found from September to October 1994, among carbonized remnants of wood.

Tephrocybe anthracophila $($ Lasch) Orton $=$ Lyophyllum sphaerospermum Kühn. et Romagn. - found occasionally among carbonized remnants of wood in autumn 1994.

\section{Sclerodermatales}

Scleroderma bovista Fr. - two sporophores found once in mid-December 1994, on sandy soil. The sporophores were overripe and most of the spores spread out.

Scleroderma citrinum Pers. - found only at the end of September and at the beginning of October 1994, on sandy soil on the border of the postfire site.

We would like to thank Dr Z. Heinrich from the Institute of Botany PAN (Polish Academy of Sciences) for the identification of two species of fungi (Galerina phillipsi and Gymmopihs fulgens) and mgr inz. B. Szczepanowicz from the Department of Plant Ecology, Jagiellonian University, Cracow for the soil analyses performed.

\section{REFERENCES}

B r a n d A. W, P e g I e r D. N. 1991. Profiles of fungi 39. Psathyrella pennata (Fr.) Konrad et Maubl. The Mycologist 5 (4): 170.

G i n k o B. 1984. Notes on Ascomycetes from burnt forest in Poland. Acta Mycol. 20 (2): 273-275.

M o s e r M. 1949. Untersuchungen über den Einfluss von Waldbränden auf die Pilzvegetation I. Sydowia, Ann. Mycol. 3 (1/6): 336-383.

Peters e n P. M. 1970. Danish fireplace fungi. Dansk Bot. Arkiv 27 (3): 1-97.

R e i d D. A. 1984. A revision of the British species of Naucoria sensu lato. Trans. Brit. Mycol. Soc. 82 (2): $191-237$.

T u r n u K. 1984. Post-fire cup-fungi of Turbacz and Stare Wierchy mountains in the Gorce range (Polish Western Carpathians). Zesz. Nauk. U.J, Prace Bot. 12: 145-170. 


\title{
Macromycetes pożarzyska leśnego w nadleśnictwie Chrzanów
}

\author{
Streszezenie
}

Praca zawiera wyniki badan nad grzybami wielkoowocnikowymi (macromycetes) owocującymi w spalonym lesie w Leśnictwie Byczyna w pobliżu Chrzanowa (woj. katowickie). Poźar mial miejsce w zespole leśnym Vaccinio uliginosi-Pinetum, w dniu 28 czerwea 1992 roku i trwat do 13 lipca. W tym czasie spaleniu ulegto 19.9 ha lasu, w oddziałach nr. $47 f$ i $47 \mathrm{~d}$. Obserwacje mikologiczne byly wykonywane w odstępach przeciętnie dwutygodniowych, w sezonach wegetacyjnych 1993 i 1994 roku. Pierwsza obserwacja miala micjsce w 20 . tygodniu po pożarze. W czasic każdorazowej obserwacji notowano obecnośc poszczególnych gatunków grzybỏw w spalonym lesie. W ciągu dwu lat zanotowano owocowanie 51 gatunków grzybów i 3 gatunków śluzowców. Grzyby należaly do dwu klas: Ascomycetes (9 gatunków) i Basidionycetes (42 gatunki). Najpospolitszym grzybem na terenic spalonego lasu byl luskwiak wypaleniskowy Pholiota carbonaria: 29 notowań na 32 obserwacje. Odrębną grupę stanowily grzyby związane ze szezątkami drewna $\mathrm{i}$ nadpalonymi gałęziami, których sporo lezalo w sciólce spalonego lasu.

Pojawy grzybów w badanym lesie w okresie wiosennym i jesiennym byly bardzo charakterystyczne: owocowanie rozpoczynalo się na wiosnę bardzo wcześnie (w drugiej polowie kwietnia) i trwało przez caly sezon wegetacyjny aź do późnej jesieni (nawet do drugiej polowy grudnia).

Oprócz badań florystycznych dotyczących wystẹpowania macromycetes w spalonym lesic, wykonywano równicz badania autekologicne nad owocowaniem Pholiota carbonaria w ciągu dwu sezonów wegetacyjnych. W tym celu wyznaczono 8 kwadratów obserwacyjnych, każdy o powierzchni $1 \mathrm{~m}^{2}$. Kwadraty te byly badane 4 razy w 1993 roku $\$ 9$ razy w 1994 roku. Za każdym razem notowano liczbę znalezionych owocników Pholiota carbonaria. Porównanie wyników obserwacji wykonanych w ciagu obu lat wykazalo duże róźnice: w 1993 roku owocowanie bylo bardzo oblite - natomiast w 1994 roku bardzo skape (Tab. 2). Na tak uderzające różnice w owocowaniu grzybów w obu latach mogly wplynąc trzy przyczyny: (1) odmienne warunki atmosferyczne panujące w obu latach: rok 1993 charakteryzowal sif obfitymi opadami atmosferycznymi przy równoczesnych wysokich temperaturach, natomiast w roku 1994 lato bylo bardzo suche i upalne, co wplynęlo bardzo ujemnie na owocowanie grzybów: (2) naturalne wyczerpanie żywotności grzybni w 1994 roku w związku z obfitą produkcją owocników w roku poprzednim; (3) pojawienie się nowych roślin i grzybów stanowiących konkurencje dla Pholiota carbonaria.

Na koricu pracy podano pelną listę grzybów znalezionych w obu sezonach wegetacyjnych w spalonym lesie w Leśnictwie Byczyna. 